\title{
Distribution of Gene Mutations Associated with Familial Normosmic Idiopathic Hypogonadotropic Hypogonadism
}

\author{
Fatih Gürbüz1, L. Damla Kotan2, Eda Mengen1, Zeynep Şıklar3, Merih Berberoğlu3, Sebila Dökmetaş4, \\ Mehmet Fatih Kılıçlı4, Ayla Güven5, Birgül Kirel6, Nurçin Saka7, Şükran Poyrazoğlu7, Yaşar Cesur8, \\ Murat Doğan8, Samim Özen9, Mehmet Nuri Özbek10, Hüseyin Demirbilek10, M. Burcu Kekil2, \\ Fatih Temiz1, Neslihan Önenli Mungan1, Bilgin Yüksel1, Ali Kemal Topaloğlu1,2 \\ ${ }^{1}$ Cukurova University Faculty of Medicine, Department of Pediatric Endocrinology, Adana, Turkey \\ ${ }^{2}$ Çukurova University Institute of Sciences, Department of Biotechnology, Adana, Turkey \\ ${ }^{3}$ Ankara University Faculty of Medicine, Department of Pediatric Endocrinology, Ankara, Turkey \\ ${ }^{4}$ Cumhuriyet University Faculty of Medicine, Department of Endocrinology, Sivas, Turkey \\ ${ }^{5}$ Göztepe Educational and Research Hospital, Department of Pediatric Endocrinology, Istanbul, Turkey \\ ${ }^{6}$ Osmangazi University Faculty of Medicine, Department of Pediatric Endocrinology, Eskişehir, Turkey \\ 7 Istanbul University Faculty of Medicine, Department of Pediatric Endocrinology, Istanbul, Turkey \\ ${ }^{8}$ Yüzüncü Yıl University Faculty of Medicine, Department of Pediatric Endocrinology, Van, Turkey \\ ${ }^{9}$ Mersin Children's Hospital, Department of Pediatric Endocrinology, Mersin, Turkey \\ ${ }^{10}$ Diyarbakır Children's Hospital, Department of Pediatric Endocrinology, Diyarbakır, Turkey
}

\section{ABSTRACT}

Objective: Normosmic idiopathic hypogonadotropic hypogonadism (nIHH) is characterized by failure of initiation or maintenance of puberty due to insufficient gonadotropin release, which is not associated with anosmia/hyposmia. The objective of this study was to determine the distribution of causative mutations in a hereditary form of $\mathrm{nlHH}$.

Methods: In this prospective collaborative study, 22 families with more than one affected individual (i.e. multiplex families) with $\mathrm{nIHH}$ were recruited and screened for genes known or suspected to be strong candidates for $\mathrm{nHHH}$.

Results: Mutations were identified in five genes (GNRHR, TACR3, TAC3 $K I S S 1 R$, and KISS1) in 77\% of families with autosomal recessively inherited $\mathrm{nIHH}$. GNRHR and TACR3 mutations were the most common two causative mutations occurring with about equal frequency.

Conclusions: Mutations in these five genes account for about three quarters of the causative mutations in $\mathrm{nlHH}$ families with more than one affected individual. This frequency is significantly greater than the previously reported rates in al inclusive (familial plus sporadic) cohorts. GNRHR and TACR3 should be the first two genes to be screened for diagnostic purposes. Identification of causative mutations in the remaining families will shed light on the regulation of puberty. Key words: Normosmic idiopathic hypogonadotropic hypogonadism, gene, mutation

Conflict of interest: None declared

Received: 30.05 .2012
Accepted: 18.06 .2012

\section{Introduction}

Idiopathic hypogonadotropic hypogonadism $(\mathrm{IHH})$ is characterized by failure of initiation or maintenance of puberty due to insufficient gonadotropin release for unknown reasons. These patients do not develop secondary sexual characteristics and their reproductive system remains immature. When the embryonic migration of gonadotropin-releasing hormone $(\mathrm{GnRH})$ neurons from the nasal placode to their final destination in the hypothalamus is disrupted, the resulting phenotype is Kallmann syndrome, which is clinically characterized by hypogonadotropic hypogonadism and anosmia, while the term normosmic $\mathrm{IHH}$ $(\mathrm{nlHH})$ denotes those $\mathrm{IHH}$ cases which not associated with anosmia/hyposmia (1). $\mathrm{nlHH}$-causing mutant genes in familial cases of $\mathrm{nlHH}$ have brought invaluable insight to the governance of the hypothalamo-pituitary-gonadal axis including puberty. Identification of mutations in consecutive patients in familial cases of $\mathrm{nlHH}$ in a set time period in a highly consanguineous society may provide clues for the specific genetic etiology as well as for the

Address for Correspondence

Ali Kemal Topaloğlu MD, Çukurova University Faculty of Medicine, Department of Pediatric Endocrinology, Balcall, Adana, Turkey

Phone: +90 3223387083 E-mail: ktopaloglu@cu.edu.tr

(c) Journal of Clinical Research in Pediatric Endocrinology, Published by Galenos Publishing. 
potential for novel genes taking part in the pubertal process. The prevalence of $\mathrm{IHH}$ has been estimated to be around 1-10/100 000 and known genetic defects have been reported to account for only $30-50 \%$ of all cases with $\mathrm{nIHH}(2,3)$.

In this paper, we report all identified causative mutations in multiplex families with $\mathrm{nlHH}$ over the past seven years in Turkey. Our findings indicate that a significant proportion of familial cases are accounted for by five genes (GNRHR, TACR3, TAC3, KISS1R, and KISS1).

\section{Methods}

The diagnosis of $\mathrm{nlHH}$ in this cohort was based on the absence of any signs of spontaneous puberty by age 13 in girls (Tanner breast stage 1) and by age 14 in boys (testicular volume $<4 \mathrm{~mL}$ ), a bone age of 11.5 years or greater, with concentrations of testosterone and estradiol at hypogonadal levels $[<20 \mathrm{ng} / \mathrm{dL}(714 \mathrm{pmol} / \mathrm{L})$ and $<1.9 \mathrm{ng} / \mathrm{dL}(73 \mathrm{pmol} / \mathrm{L})$, respectively] in the setting of inappropriately normal or low gonadotropin levels. All patients had normal levels of free thyroxine, thyroid stimulating hormone, prolactin, insulin-like growth factor-1, adrenocorticotropic hormone, and cortisol. They had no evidence of structural lesions on imaging of the hypothalamic-pituitary region. Cases with chronic systemic diseases (e.g. uremia, thalassemia, poorly controlled diabetes mellitus), eating disorders (e.g. anorexia nervosa, bulimia), or protein energy malnutrition were excluded from the study. Individuals with body mass indices corresponding to extreme thinness or obesity were also excluded. All subjects had a normal sense of smell on conventional testing. No case had features suggestive of Bardet-Biedl, Biemond, Prader-Willi, or any other syndromes. The cohort included consecutive patients who were recruited through the collaboration of several national institutions in Turkey, over the past seven years. The study was approved by the ethics committee of Çukurova University Faculty of Medicine. Written consent was obtained from all patients or their legal guardians, if under 18 years of age.

\section{Clinical and Hormonal Studies}

Serum luteinizing hormone (LH), follicle-stimulating hormone (FSH), estradiol, and testosterone levels were measured by immunofluorometric assays. A GnRH stimulation test $(2.5 \mu \mathrm{g} / \mathrm{kg}$, maximum $100 \mu$ g, i.v.) was performed in all subjects, and serum $\mathrm{LH}$ and FSH levels were measured at 0, 15, 30, 45, and 60 min after $\mathrm{GnRH}$ stimulation. Olfactory bulbs and sulci and hypothalamic-pituitary structures were analyzed by magnetic resonance imaging.

Table 1. Reference data on families with gene mutations associated with nIHH phenotype

\begin{tabular}{lll}
\hline Family Number & Gene & Mutation \\
\hline 1 & GnRH & p.R139C \\
2 & GnRH & p.R139C \\
3 & GnRH & p.N10K, Q11K \\
4 & GnRH & R2620, p.X329WextX22 \\
5 & GnRH & p.R139H \\
6 & GnRH & p.M131T \\
7 & GnRH & p.L117R \\
8 & TACR3 & p.P353S \\
9 & TACR3 & p.P353S \\
10 & TACR3 & p.G93D \\
11 & TACR3 & p.H148L \\
12 & TACR3 & \\
13 & TACR3 & \\
14 & TAC3 & \\
15 & KISS1 & p.M90T \\
16 & KISS1R & \\
17 & KISS1R &
\end{tabular}

Reference

Topaloglu et al (4)

This paper and Topaloglu et al (4)

This paper and Meysing et al (29)

This paper

This paper article; Costa et al (17) and Wolczynski et al (24)

This paper

This paper

Topaloglu et al (5)

Topaloglu et al (5)

Topaloglu et al (5)

Guran et al (6)

Gurbuz et al (paper submitted for publication)

Gurbuz et al (paper submitted)

Topaloglu et al (5)

Topaloglu et al (7)

Ozbek et al (paper submitted)

Ozbek et al (paper submitted) 


\section{DNA Sequencing}

DNA was extracted from blood leukocytes using standard methods. The coding regions and neighboring intronic regions of the known or strong candidate genes for $\mathrm{nlHH}$ (GNRHR, GNRH1, TACR3, TAC3, KISS1R, and KISS1) were amplified by polymerase chain reaction (PCR). The PCR products were purified and directly sequenced using Big Dye terminator cycle sequencing ready reaction kit (PE Applied Biosystems, Foster City, Calif., USA) in an ABI PRISM 310 automatic sequencer.

Functional consequences of the novel mutations were predicted using the Polyphen-2 program (http://genetics.bwh.harvard.edu/pph2/).

\section{Results}

All patients presented with the signs and symptoms of a typical complete $\mathrm{nlHH}$ phenotype. We identified causative mutations in 17 out of 22 (77.2\%) multiplex families with $\mathrm{nlHH}$. The most common two causes were GNRHR and TACR3 mutations. Among the 22 families, we have identified mutations of GNRHR in seven (31.8\%), TACR3 in six (27.2\%), TAC3 in one $(4.5 \%), K I S S 1$ in one $(4.5 \%)$, and KISS1R in two $(9 \%)$. In all of these families, the mutations segregated within the respective nuclear families according to the rules of autosomal recessive inheritance. In five families, we have not been able to find mutations in any of these genes (Figure 1, Table 1). A summary of the findings in the 17 families is given below.

Family 1: We have previously reported this family and its two members (two sisters) with absent breast development and primary amenorrhea due to p.R139C mutation in the GNRHR gene (4).

Family 2: The proband was a 15.4-year-old boy who presented with small testes. His two elder brothers were of the same clinical phenotype. Their parents were healthy cousins. The proband's height was $177.5 \mathrm{~cm}$ and he weighed $59 \mathrm{~kg}$. His pubic hair and axillary hair were at Tanner stage 3 and 2, respectively. Testis volume was $2 \mathrm{~mL}$ bilaterally. His stretched penile length was $4 \mathrm{~cm}$. His bone age was 13 years. His basal testosterone level was $<0.01 \mathrm{ng} / \mathrm{dL}$. LH and FSH levels were 0.11 and $0.23 \mathrm{mlU} / \mathrm{mL}$, respectively. A GnRH stimulation test produced maximal LH and FSH levels of 1.2 and $1.6 \mathrm{mlU} / \mathrm{mL}$,

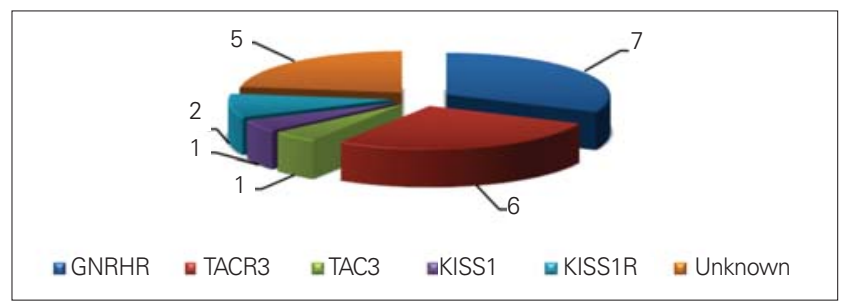

Figure 1. Distribution of the causative mutations in 22 families of patients with normosmic idiopathic hypogonadotropic hypogonadism respectively. The patient had a normal male karyotype. In this family also, the mutation analysis revealed p.R139C mutation in the GNRHR gene.

Family 3: The proband was a 14.3-year-old boy who presented with micropenis and small testes. His past medical history was unremarkable except for left orchidopexy surgery at the age of one year. The parents were healthy distant cousins. The proband was $150 \mathrm{~cm}$ tall and weighed $53 \mathrm{~kg}$. Both his pubic hair and axillary hair were at stage 2. His testes were bilaterally in the scrotum and measured $3 \mathrm{~mL}$. His stretched penile length was $4 \mathrm{~cm}$. His bone age was 13.6 years. Magnetic resonance imaging of the brain revealed normal olfactory bulbs and sulci and normal hypothalamic-pituitary structures. His basal testosterone level was $<20 \mathrm{ng} / \mathrm{dL}$ with LH and FSH levels of 0.22 and $0.9 \mathrm{mlU} / \mathrm{mL}$, respectively. A GnRH stimulation test produced a maximal $\mathrm{LH}$ level of $8.1 \mathrm{mlU} / \mathrm{mL}$. He had a normal male karyotype. His 19-year-old sister was reported to have absent breast development and primary amenorrhea. The patients in family 3 showed p.N10K (from mother) and p.Q11K (from father) compound heterozygous mutations in the GNRHR gene.

Family 4: The proband was a 29-year-old man who had presented at age 16 with micropenis and small testes. His two elder brothers were of the same clinical phenotype. Their parents were not related. The proband's height was $182 \mathrm{~cm}$ and he weighed $69 \mathrm{~kg}$. His pubic and axillary hair was at Tanner stage 1. His testes were $3 \mathrm{~mL}$ bilaterally in the scrotum. His stretched penile length was $3 \mathrm{~cm}$. His bone age was 18 years. His basal testosterone level was $40 \mathrm{ng} / \mathrm{dL}$ with $\mathrm{LH}$ and FSH levels of 1.31 and $1.4 \mathrm{mlU} / \mathrm{mL}$, respectively. $\mathrm{A} \mathrm{GnRH}$ stimulation test produced maximal LH and FSH levels of 8.1 and $4.89 \mathrm{mIU} / \mathrm{mL}$, respectively. He had a normal male karyotype. The patients in family 4 showed p.R262Q (from mother) and p.X329W (from father) compound heterozygous mutations in the GNRHR gene.

Family 5: The proband was a 2-month-old boy who presented with micropenis of $1.6 \mathrm{~cm}$ and small testes. His past medical history was unremarkable. He was born after an uncomplicated pregnancy with a $3.2-\mathrm{kg}$ birth weight. A 3-year-8-month-old brother was of the same clinical phenotype. Their parents were healthy cousins. This family has $\mathrm{p} . \mathrm{R} 139 \mathrm{H}$ mutation in the GNRHR gene.

Family 6: The proband was a 27-year-old man who had presented with small testes at age 15 . His parents were healthy cousins. His pubic and axillary hair was at Tanner stage 3. His testes were $3 \mathrm{~mL}$ bilaterally in the scrotum. His stretched penile length was $6 \mathrm{~cm}$. His testosterone level was $82 \mathrm{ng} / \mathrm{dL}$ with $\mathrm{LH}$ and $\mathrm{FSH}$ levels of 0.18 and $1.06 \mathrm{mlU} / \mathrm{mL}$, respectively, while on treatment with monthly testosterone injections. A $\mathrm{GnRH}$ stimulation test produced maximal $\mathrm{LH}$ and FSH levels of 0.69 and $0.93 \mathrm{mlU} / \mathrm{mL}$, respectively. He had a normal male karyotype. His 2 years older brother was reported to have a similar phenotype. The patients in this family have the novel 
mutation of p.M131T in the GNRHR gene. Polyphen 2 analysis indicated that the mutation p.M131T is probably damaging with a score of 0.99 out of 1.0 .

Family 7: The proband was an 18.3-year-old boy who presented with micropenis and small testes. One younger brother was of the same clinical phenotype. Their parents were not related. The proband was $180 \mathrm{~cm}$ tall and weighed $51 \mathrm{~kg}$. His pubic hair and axillary hair were at Tanner stage 3 . His testes were $2 \mathrm{~mL}$ bilaterally in the scrotum. His stretched penile length was $3.7 \mathrm{~cm}$. His bone age was 13 years. His basal testosterone level was $28.8 \mathrm{ng} / \mathrm{dL}$ with $\mathrm{LH}$ and $\mathrm{FSH}$ levels of $<0.07$ and 0.18 $\mathrm{mIU} / \mathrm{mL}$, respectively. A GnRH stimulation test produced maximal $\mathrm{LH}$ and $\mathrm{FSH}$ levels of 0.22 and $0.81 \mathrm{mIU} / \mathrm{mL}$, respectively. He had a normal male karyotype. Family 7 has the novel mutation of p.L117R in the GNRHR gene. Polyphen 2 analysis indicated that the mutation P.L117R is probably damaging with a score of 0.97 out of 1.0 .

Families 8, 9, 10, and 11: We have previously reported TACR3 mutations in these families $(5,6)$.

Families 12 and 13: These two unrelated families have the same novel missense mutation in the TACR3 gene. Detailed reports of these two families have been submitted for publication (unpublished date).

Family 14: We have previously reported p.M90T mutation in the TAC3 gene in this family (5).

Family 15: We have previously reported p.N115K mutation in the KISS1 gene in this family (7).

Families 16 and 17: These two unrelated families have the same novel missense mutation in the KISS1R gene. Detailed reports of these two families have been submitted for publication (unpublished date).

\section{Discussion}

Known genetic defects have been reported to account for about $30-50 \%$ of all $\mathrm{IHH}$ cases $(2,3)$ In large cohorts, the percentage of familial cases appear to vary between 6.3 to 25 $(8,9,10)$. It is well known that the possibility of finding a gene mutation is significantly greater for familial cases as compared to sporadic ones. For example, KISS1R mutations were found as 3 out of $180(1.6 \%)$ in sporadic cases, while this frequency was 5 out of $24(20.8 \%)$ in familial cases (11). However, this distinction between sporadic and familial cases is not clear in all studies. Au et al (12) found mutations in $44 \%$ of a large cohort consisting of $\mathrm{IHH}$ patients. It is not clear how many of those probands came from multiplex families nor how many of those probands were cases of $\mathrm{nlHH}$. In this study, we therefore focused exclusively on well described and almost uniform familial cases. Multiplex families with $\mathrm{nIHH}$ are more likely to be encountered in the Turkish population, which has a consanguinity rate of $21 \%$, than in western societies (13). Consistently, in this study, we report identification of causative mutations in 17 families out of 22 families $(77.2 \%)$ with $\mathrm{nlHH}$, a finding which reflects a significantly higher percentage as compared to previous studies $(2,3)$. Mutations in five genes (GNRHR, TACR3, TAC3, KISS1R, and KISS1) account for about three quarters of families with $\mathrm{nlHH}$ cases. Two genes, GNRHR and TACR3, are most likely to be found among familial cases. Therefore, these should be the first two genes to be screened in the molecular genetic diagnosis of $\mathrm{nlHH}$.

Large scale screening indicates that GNRHR mutations account for $3.5-16 \%$ of sporadic cases of $\mathrm{nlHH}$ and up to $40 \%$ of familial cases (14). Beranova et al (15) reported GNRHR mutations in two of the 5 families with autosomal recessive pedigrees. In our study, we identified GNRHR gene mutations in seven of 22 families (31.8\%) with $\mathrm{nlHH}$. Thus, in our study, the rate of identified GNRHR gene mutations in $\mathrm{nlHH}$ phenotype was approximately the same as the previously reported rates for familial cases.

Most of the mutations (5 of 7) in GNRHR have been previously reported. To date, 22 mutations in GNRHR have been described; the most common mutations were $\mathrm{Q} 106 \mathrm{R}$ and $\mathrm{R} 262 \mathrm{O}$ $(15,16,17,18,19,20,21,22,23)$. The p.R139C mutation in the GNRHR gene was reported by one of us in family 1 (4), and family 2 harbored the same mutation (p.R139C). These two families are not known to be related to each other. The p.R139H mutation found in family 5 in the GNRHR gene has also been previously reported in Brazilian and Polish patients with $\mathrm{nlHH}(17,24)$. As the patients in family 5 have a mutation in the same residue as family 1 and 2, arginine at position 139 could be considered a mutational hotspot. Chevrier et al (25) observed 17 of 269 patients bearing compound heterozygote or homozygote GNRHR mutations. However, in this report, it is not clear how many of those patients came from multiplex families. The p.R262O in the GNRHR gene has previously been reported in homozygous or compound heterozygous state $(16,18,19,22,26,27,28)$. In our family 4, R262O was in compound heterozygous state with p.X329WextX22, which is a novel mutation predicted to be deleterious due to 22 amino acid longer derivative protein. Likewise, compound heterozygous states for p.N10K and p.Q11K mutations in GNRHR gene have been reported previously (29).

The p.M131T mutation in family 6 and p.L117R mutation in family 7 in the GNRHR gene have not been reported previously. These novel mutations were predicted to be deleterious by Polyphen-2 analysis as these residues are highly preserved through evolution. The phenotype associated with these mutations is indistinguishable from the previously reported mutations discussed above.

TACR3 and TAC3 gene mutations have been first described by us (5). In a large multiethnic study, Gianetti et al (30) found TACR3 mutations in 5.5\% of the whole cohort consisting of 345 $\mathrm{nlHH}$ probands. Among them, four out of 37 Turkish probands had TACR3 mutations (10.8\%). However, it is not clear how many of these Turkish probands came from multiplex families. In 2011, 
Francou et al (31) identified three families with nine patients carrying TAC3 or TACR3 variants (5.2\%) among $173 \mathrm{nlHH}$ cases. In that article, there was only one multiplex family who showed a homozygous TACR3 deletion (c.483_499del). In our study, we have identified mutations in the TACR3 gene in six of the 22 families $(27.2 \%)$, a frequency, significantly greater than the previously reported rates for the TACR3 gene mutations. One possible explanation for this could be that our probands come from clearly autosomal recessive pedigrees.

In summary, a significantly higher percentage of patients with familial $\mathrm{nlHH}$ have monogenic mutations when compared to sporadic cases. GNRHR and TACR3 mutations are the most common two mutated genes to account for the $\mathrm{nlHH}$. "Identification of mutations in consecutive patients in familial cases of $\mathrm{nlHH}$ in a set time period in a highly consanguineous society may provide true picture of genetic etiology as well as potential for novel genes taking part in pubertal process."

\section{References}

1. Semple RK, Topaloglu AK. Neurokinin B and its receptor in hypogonadotropic hypogonadism. Front Horm Res 2010;39:133-141. (Epub 2010 Apr 8)

2. Bianco SD, Kaiser UB. The genetic and molecular basis of idiopathic hypogonadotropic hypogonadism. Nat Rev Endocrinol 2009;5:569-576. (Epub 2009 Aug 25)

3. Crowley WF Jr, Pitteloud N, Seminara S. New genes controlling human reproduction and how you find them. Trans Am Clin Climatol Assoc 2008;119:29-37.

4. Topaloglu AK, Lu ZL, Farooqi IS, Mungan NO, Yuksel B, O'Rahilly $\mathrm{S}$, Millar RP. Molecular genetic analysis of normosmic hypogonadotropic hypogonadism in a Turkish population: identification and detailed functional characterization of a novel mutation in the gonadotropin-releasing hormone receptor gene. Neuroendocrinology 2006:84:301-308.

5. Topaloglu AK, Reimann F, Guclu M, Yalin AS, Kotan LD, Porter KM, Serin A, Mungan NO, Cook JR, Ozbek MN, Imamoglu S, Akalin NS, Yuksel B. TAC3 and TACR3 mutations in familial hypogonadotropic hypogonadism reveal a key role for Neurokinin B in the central control of reproduction. Nat Genet 2009;41:354-358. (Epub 2009 Dec 11)

6. Guran T, Tolhurst G, Bereket A, Rocha N, Porter K, Turan S, Gribble FM, Kotan LD, Akcay T, Atay Z, Canan H, Serin A, O'Rahilly S, Reimann F, Semple RK, Topaloglu AK. Hypogonadotropic hypogonadism due to a novel missense mutation in the first extracellular loop of the neurokinin b receptor. J Clin Endocrinol Metab 2009;94:3633-3639. (Epub 2009 Sep 15)

7. Topaloglu AK, Tello JA, Kotan LD, Ozbek MN, Yilmaz MB Erdogan S, Gurbuz F, Temiz F, Millar RP, Yuksel B. Inactivating KISS1 Mutation and Hypogonadotropic Hypogonadism. N Engl J Med 2012;366:629-635.

8. Bhagavath B, Podolsky RH, Ozata M, Bolu E, Bick DP Kulharya A, Sherins RJ, Layman LC. Clinical and molecular characterization of a large sample of patients with hypogonadotropic hypogonadism. Fertil Steril 2006;85:706-713.

9. Waldstreicher J, Seminara SB, Jameson JL, Geyer A, Nachtigall LB, Boepple PA, Holmes LB, Crowley WF Jr. The genetic and clinical heterogeneity of gonadotropin-releasing hormone deficiency in the human. J Clin Endocrinol Metab 1996;81:4388-4395.
10. Quinton R, Duke VM, Robertson A, Kirk JM, Matfin G, de Zoysa PA, Azcona C, MacColl GS, Jacobs HS, Conway GS, Besser M, Stanhope RG, Bouloux PM. Idiopathic gonadotrophin deficiency: genetic questions addressed through phenotypic characterization. Clin Endocrinol (Oxf) 2001;55:163-174.

11. Silveira LFG, Trarbach EB, Latronico AC. Genetics basis for $\mathrm{GnRH}$-dependent pubertal disorders in humans. Mol Cell Endocrinol 2010:324:30-38. (Epub 2010 Feb 25)

12. Au MG, Crowley WF, Buck CL. Genetic counseling for isolated GnRH deficiency. Mol Cell Endocrinol 2011;346:102-109. (Epub 2011 Jun 11)

13. Tuncbilek $\mathrm{E}, \mathrm{Koc}$ I. Consanguineous marriage in Turkey and its impact on fertility and mortality. Ann Hum Genet 1994;58:321329

14. Bedecarrats GY, Kaiser UB. Mutations in the human gonadotropin-releasing hormone receptor: Insights into receptor biology and function. Semin Reprod Med 2007:25:368-378

15. Beranova M, Oliveira LM, Bedecarrats GY, Schipani E, Vallejo M, Ammini AC, Quintos JB, Hall JE, Martin KA, Hayes FJ, Pitteloud N, Kaiser UB, Crowley WF Jr. Prevalence, phenotypic spectrum, and modes of inheritance of gonadotropin-releasing hormone receptor mutations in idiopathic hypogonadotropic hypogonadism. J Clin Endocrinol Metab 2001;86:1580-1588.

16. Caron $P$, Chauvin $S$, Christin-Maitre $S$, Bennet $A$, Lahlou N Counis R, Bouchard P, Kottler ML. Resistance of hypogonadic patients with mutated $\mathrm{GnRH}$ receptor genes to pulsatile $\mathrm{GnRH}$ administration. J Clin Endocrinol Metab 1999;84:990-996.

17. Costa EM, Betecarrats GY, Mendonca BB, Arnhold IJ, Kaiser UB, Latronico AC. Two novel mutations in the gonadotropinreleasing hormone receptor gene in Brazilian patients with hypogonadotropic hypogonadism and normal olfaction. J Clin Endocrinol Metab 2001:86:2680-2686.

18. de Roux N, Young J, Misrahi M, Genet R, Chanson P, Schaison G, Milgrom E. A family with hypogonadotropic hypogonadism and mutations in the gonadotropin-releasing hormone receptor. N Engl J Med 1997;337:1597-1602.

19. de Roux N, Young J, Brailly-Tabard S, Misrahi M, Milgrom E, Schaison G. The same molecular defects of the gonadotropinreleasing hormone receptor determine a variable degree of hypogonadism in affected kindred. J Clin Endocrinol Metab 1999:84:567-572

20. Karges B, Karges W, Mine M, Ludwig L, Kühne R, Milgrom E, de Roux N. Mutation Ala(171)Thr stabilizes the gonadotropinreleasing hormone receptor in its inactive conformation, causing familial hypogonadotropic hypogonadism. J Clin Endocrinol Metab 2003;88:1873-1879.

21. Kottler ML, Chauvin S, Lahlou N, Harris CE, Johnston CJ, Lagarde JP, Bouchard P, Farid NR, Counis R. A new compound heterozygous mutation of the gonadotropin-releasing hormone receptor (L314X, Q106R) in a woman with complete hypogonadotropic hypogonadism: chronic estrogen administration amplifies the gonadotropin defect. J Clin Endocrinol Metab 2000;85:3002-3008.

22. Layman LC, Cohen DP, Jin M, Xie J, Li Z, Reindollar RH, Bolbolan S, Bick DP, Sherins RR, Duck LW, Musgrove LC, Sellers JC, Neill JD. Mutations in gonadotropin-releasing hormone receptor gene cause hypogonadotropic hypogonadism. Nat Genet 1998;18:14-15.

23. Pitteloud N, Boepple PA, DeCruz S, Valkenburgh SB, Crowley WF Hayes FJ. The fertile eunuch variant of idiopathic hypogonadotropic hypogonadism: Spontaneous reversal associated with a homozygous mutation in the gonadotropinreleasing hormone receptor. J Clin Endocrinol Metab 2001:86:2470-2475 
Gürbüz $F$ et al.

Gene Mutations in Idiopathic Hypogonadotropic Hypogonadism

24. Wolczynski S, Laudonski P, Jarzabek K, Mittre H, Lagarde JP, Kottler ML. A case of complete hypogonadotropic hypogonadism with a mutation in the gonadotropin-releasing hormone receptor gene. Fertil Steril 2003;79:442-444.

25. Chevrier L, Guimiot F, de Roux N. GnRH receptor mutations in isolated gonadotropic deficiency. Mol Cell Endocrinol 2011;346:21-28. (Epub 2011 Apr 30)

26. Lin L, Conway GS, Hill NR, Dattani MT, Hindmarsh PC Achermann JC. A homozygous $\mathrm{R} 262 \mathrm{Q}$ mutation in the gonadotropin-releasing hormone receptor presenting as constitutional delay of growth and puberty with subsequent borderline oligospermia. J Clin Endocrinol Metab 2006;91:5117-5121. (Epub 2006 Sep 12)

27. Seminara SB, Oliveira LM, Beranova M, Hayes FJ, Crowley WF Jr. Genetics of hypogonadotropic hypogonadism. J Endocrinol Invest 2000;23:560-565.

28. Kim HG, Pedersen-White J, Bhagavath B, Layman LC. Genotype and phenotype of patients with gonadotropin-releasing hormone receptor mutations. Front Horm Res 2010;39:94-110. (Epub 2010 Apr 8)
29. Meysing AU, Kanasaki H, Bedecarrats GY, Acierno JS, Conn PM, Martin KA, Seminara SB, Hall JE, Crowley WF Jr, Kaiser UB. GNRHR mutations in a woman with idiopathic hypogonadotropic hypogonadism highlight the differential sensitivity of luteinizing hormone and follicle-stimulating hormone to gonadotropin-releasing hormone. J Clin Endocrinol Metab 2004;89:3189-3198.

30. Gianetti E, Tusset C, Noel SD, Au MG, Dwyer AA, Hughes VA, Abreu AP, Carroll J, Trarbach E, Silveira LF, Costa EM, de Mendonça BB, de Castro M, Lofrano A, Hall JE, Bolu E, Ozata M, Quinton R, Amory JK, Stewart SE, Arlt W, Cole TR, Crowley WF, Kaiser UB, Latronico AC, Seminara SB. TAC3/TACR3 Mutations Reveal Preferential Activation of Gonadotropin-Releasing Hormone Release by Neurokinin B in Neonatal Life Followed by Reversal in Adulthood. J Clin Endocrinol Metab 2010;95:2857-2867. (Epub 2010 Mar 23)

31. Francou B, Bouligand J, Voican A, Amazit L, Trabado S, Fagart J, Meduri G, Brailly-Tabard S, Chanson P, Lecomte P, GuiochonMantel A, Young J. Normosmic congenital hypogonadotropic hypogonadism due to TAC3/TACR3 mutations: characterization of neuroendocrine phenotypes and novel mutations. PLoS One 2011;6:25614. (Epub 2011 Oct 2) 